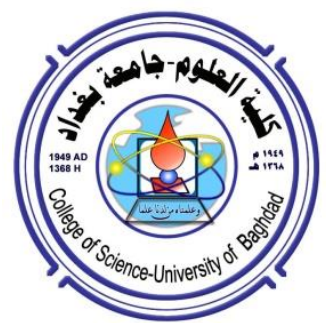

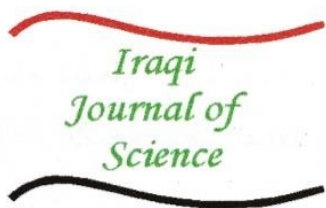

ISSN: 0067-2904

\title{
Statistical Analysis of COVID-19 Pandemic Across the Provinces of Iraq
}

\author{
Raghad G. Ali Al-Suhail, Layla Fouad Ali \\ Biology Department, College of Science, University of Baghdad, Baghdad, Iraq
}

Received: 26/9/2020

Accepted: 7/12/2020

\begin{abstract}
The Coronavirus disease 2019 (COVID-19) pandemic is caused by the transmission of severe acute respiratory syndrome coronavirus 2 (SARS-CoV-2), which was first identified in December 2019 in Wuhan, China. The outbreak was declared as a Public Health Emergency of International Concern in January 2020 and a pandemic in March 2020. In this study, a complete statistical analysis for SARS-CoV-2 pandemic in entire Iraq, as well as for each governorate separately, is performed for the first time. The study covers a period that starts from the beginning of the pandemic, in the $24^{\text {th }}$ of February 2020, until the $16^{\text {th }}$ of July 2020. It was clear that, although the average number of the reported infection cases was low during February and March, the average infection rate (R0) was >1 (1.3- 2.1), indicating a high spreading rate. During April, when there was a complete lockdown, there was a slight decrease in the RO when the lockdown was lifted, the $\mathrm{RO}$ and the number of new cases started to increase rapidly until the $16^{\text {th }}$ of July, when the average number of new cases for every 6 days reached 2281. The cumulative average number of new cases for every six days since the beginning of the pandemic in Iraq on 16 July was $598.4 \pm 862.4$ (Mean \pm SD). The higher standard deviation than mean value (SD > mean) for most of the analyzes indicates that the official statistics are not reliable. This may be due to the need to conduct further studies as well as the presence of several cases that were not officially reported. In addition, the overall six-day average RO for entire Iraq was $1.4 \pm 0.5$, with unstable values after the start of the pandemic and absence of monitoring at any time. On the other hand, this study reflects the variations in average RO, average new cases, average recovery rates, average death rates for every 6 days between the Iraqi provinces. Bagdad reported the highest average number of new cases; Babil and Salah aldin reported the highest RO values (2.8 \pm 7.6, 2.5 \pm 7.7 , respectively). Erbil and Kurkuk reported the highest average recovery rates $(372.3 \pm 1340.8$, $158 \pm 433 \%$, respectively). Babil and Dhiqar reported the highest average death rates $(12.2 \pm 63.3,10.0 \pm 25.8 \%$, respectively), although Duhock did not record any deaths at the time of the study. The data require the attention of the Ministry of Health and Environment to fill in performance holes, as demonstrated by an out-of-control pandemic in Iraq.
\end{abstract}

Keywords: Statistical, COVID-19, pandemic, Iraq

$$
\begin{aligned}
& \text { تحليل احصائي لجائحة } 19 \text { COVID-19 في جميع محافظات العرلق } \\
& \text { رغد السهيل ، ليلى فؤاد علي }
\end{aligned}
$$

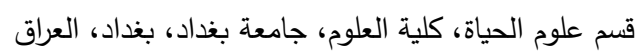

$$
\begin{aligned}
& \text { في هذه الدراسة تم عمل تحليل احصائي كامل لجائحة كورونا في العراق عموما وفي كل محافظة على حدة }
\end{aligned}
$$




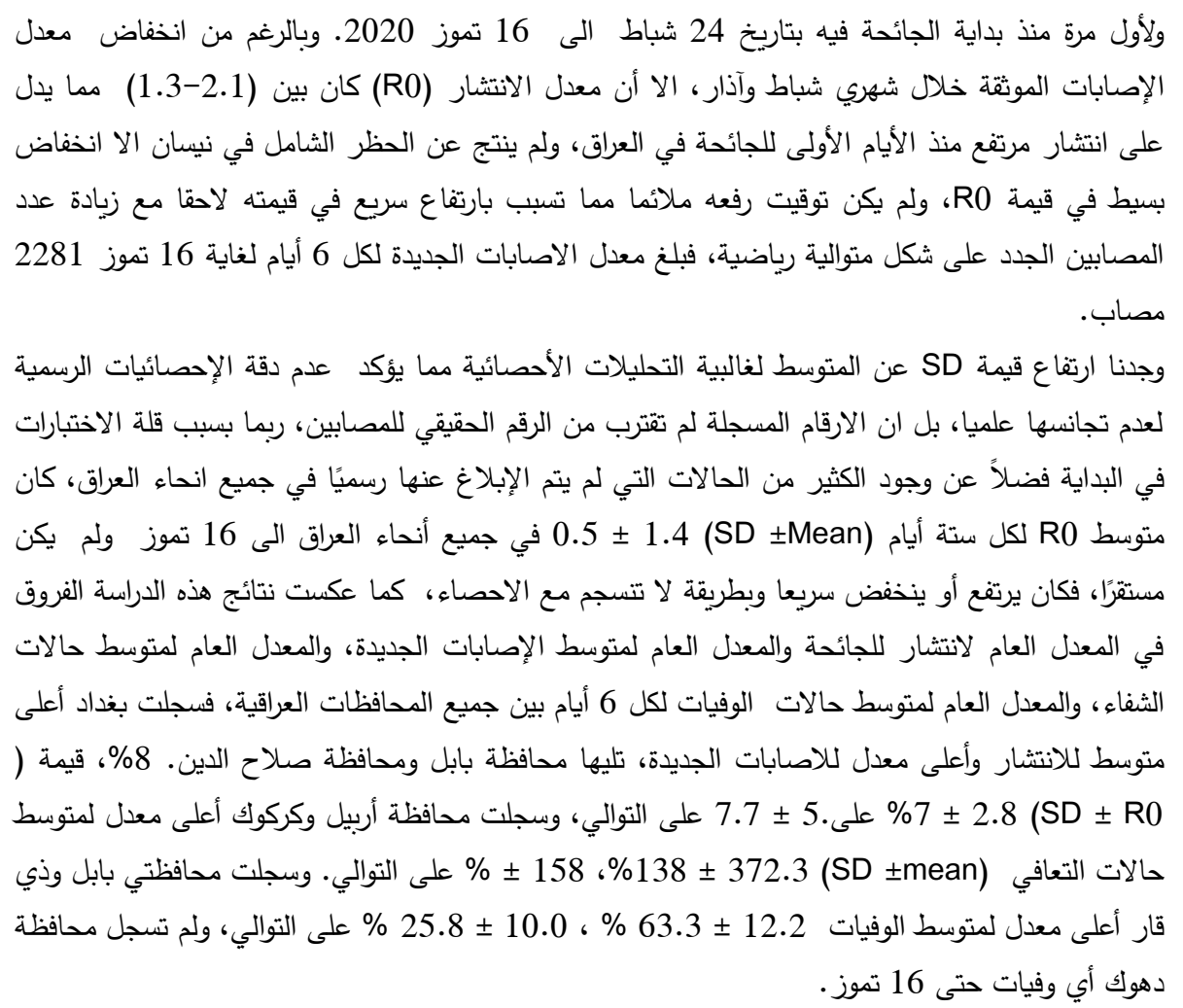

\section{Introduction}

Coronavirus disease 2019 (COVID-19) was first discovered in December 2019 in Wuhan, China. The World Health Organization announced the outbreak as a Public Health Emergency of International Concern on 30 January 2020 and a pandemic on 11 March 2020. Coronaviruses have been associated with some significant disease outbreaks in East Asia and the Middle East. The severe acute respiratory syndrome (SARS) emerged in China in 2002 and the Middle East respiratory syndromes (MERS) emerged in Saudi Arabia in 2012. The novel COVID-19, or the severe acute respiratory syndrome coronavirus 2 [SARS-CoV-2], emerged in 2019 and has been a global health threat with its ongoing pandemic in all countries [1].

SARS-CoV-2 belongs to the family Coronaviridae, subfamily Coronavirina. These viruses infect a broad range of hosts, producing several diseases ranging from mild ones, such as a common cold, to severe and fatal illnesses like SARS, MERS, and the current COVID-19 [2, 3]. Although SARSCoV-2 belongs to the same lineage of CoVs that causes SARS, this virus is genetically distinct [4]. COVID19 is one of the diseases of zoonotic origin; it is transmitted from human-to-human by different routes that involve the transmission of small droplets from the nose or mouth of infected persons through coughing, sneezing, or speaking. Early diagnosis is achieved by real-time PCR which facilitates the identification of this pathogen at any stage [5].

The novel CoVs represent a significant threat to global public health $[5,6]$. High genetic diversity of this virus and its ability to infect different host species are caused by the high frequency of mutations that result from the instability of RNA-dependent RNA polymerases [7]. The most common symptoms of COVID-19 are fever, cough, dyspnea, headache, and fatigue. Some other symptoms may include diarrhea, hemoptysis, and loss of smell and taste [8,9]. Asymptomatic individuals are suspected of potentially transmitting infections [10, 11]. About $80 \%$ of infected individuals can recover from the disease without any special treatment, especially children and young adults. However, it may cause serious illness in about $20 \%$ of infected individuals. They may develop difficulty in breathing and require medical care. Individuals aged over 60 years and those who have medical conditions like diabetes, heart disease, respiratory disease, or hypertension are among those who are at greater risk of developing severe symptoms [5].

SARS-CoV-2 is a novel virus with unknown characteristics of transmission and infection dynamics. However, several factors that affect transmission were indicated, including variation in RO value across time and populations, heterogeneity in the attack, contact rates across demographic 
groups, population density, cultural behaviors, age, and sex. All these factors affect mortality rates, which makes a uniform RO across populations not realistic. Moreover, the variation in transmissibility between individuals can play a major role in viral spread [12].

The United States Centers for Disease Control and Prevention (CDC), as well as other health agencies and institutions around the world, published several epidemiological researches on the spread of COVID-19 and its distribution in different countries. These studies indicated that the incubation period for this virus is 2 -14 days, with a mean of 5-6 days [11]. Therefore, in the present study, the average infection rates, newly recorded cases, and recovery and death rates were calculated every six days, since the start of the pandemic in Iraq to the $16^{\text {th }}$ of July, in order to identify the spectrum of the severity of the disease and understand the impact of COVID-19 on public health.

The goal of this study was to highlight the growth of the pandemic in Iraq from the outset by identifying some gaps that need scientific attention, using the statistical analysis for official data from the Iraqi governorates.

\section{Study Design}

The officially confirmed data for the numbers of new infections as well as the recovery and death cases were analyzed for Iraq as a total and each governorate separately. Statistical analysis was performed depending on the average for each parameter in 6 days, which is the expected minimal time to double the number of newly infected cases.

Values of RO were calculated using the following formula [10]:

$\mathrm{RO}=$ No. of previous cases/ No. of new cases

Data were expressed as mean \pm SD. Results and Discussion

The first case of confirmed Covid-19 infection in Iraq was recorded in the $24^{\text {th }}$ of February 2020 in Najaf governorate for a student who had arrived earlier from Iran. Then, the number of infected individuals increased gradually in the entire country. The lockdown measures did not result in a significant decrease in the number of the newly infected cases. This could be attributed to the incomplete compliance of the public with the recommended safety measures, probably due to the associated heavy economic burden.

In order to study the pandemic in Iraq since the first recorded case, statistical analysis was performed depending on the number of the officially recorded cases for the period 24 February -16 July 2020. .. This study may explain how fast the spread of the pandemic in Iraq is and highlight the gaps that need revision to control the pandemic using scientific methods.

\section{Herd Immunity in Iraq}

Herd immunity is defined as the indirect protection from contagious infectious diseases that is achieved when a certain percentage of a population becomes immune to the causative agent, either by vaccination or previous infections. It results in reducing the spread of the infection for individuals who lack immunity [12].

Herd immunity is highly dependent on the basic reproduction number (RO) of an infection, or the infection rate when the period of time to transfer the infection is included. It is defined as the expected number of cases directly generated by one infected case in a population, when all individuals are susceptible to infection [13]. When RO is $>1$ the spreading is active, while if it is $<1$ the infection is under control, and if it equals 1 it is stable [14]. However, the value of RO varies from one virus to another and from one area to another depending on many factors. The larger the Ro value the harder it is to control the infection without vaccination [12].

It is agreed now that the RO value for covid19 is 2-3 every 5-6 days [15], which means that one infected person may transfer the infection to 2-3 individuals. To calculate the number of individuals that is needed to achieve herd immunity for Covid19 in Iraq, the following equation is used: [12]

$\mathrm{RO}-1 / \mathrm{RO}=2-1 / 2=50 \%$

$3-1 / 3=67 \%$

This implies that $50-67 \%$ of the Iraq population must be immune to achieve the herd immunity. In other words, if the population is 36 million, we expect that 18-24 million individual be infected, $20 \%$ of whom will need hospitalization and special medical care [16], which is about 3.6-5 million individuals, a difficult number to handle for any country.

\section{Statistical analysis of the numbers and rate of infections}

The average number of infection cases and the infection rate every 6 days in Iraq, as well as the average of recovery and deaths, were calculated. 
It is clear from Table-1 that, although the number of cases was low at the beginning of the pandemic during February and March, the infection rates were $>1$, with a range of 1.3-2.1, reflecting a high speed of spread. It is thought that the number of the performed tests was very low, which may explain the low number of cases. During April, there was a slight decrease in the infectious rate, which may be due to the complete lockdown in Iraq. When the lockdown was lifted in May, the average number of cases every 6 days started to increase rapidly, with an infection rate of $>1$, until 16 July when average number of new cases reached 2281.3. The total average of new cases in Iraq for every six days was $598.4 \pm 862.4$. The $\mathrm{SD}$ is higher than the mean itself, reflecting that the data is not very precise, may be due to the need for more tests to be performed and the presence of many cases that were not officially registered. The total average infection rate for every six days was $1.4 \pm 0.5$ in all Iraq, reflecting that the pandemic was active. As can be observed in Figure-1, the infection rate was not stable since the beginning of the pandemic. It was commonly thought the low number of cases indicates a limited spread of the virus, which was proved to be incorrect on the basis of the current data, since a high number of cases were not detected since the beginning.

Table 1-The average infection numbers and rates for every 6 days in Iraq since the beginning of the pandemic until the $16^{\text {th }}$ of July 2020

\begin{tabular}{|c|c|c|c|c|}
\hline Month & Date & $\begin{array}{l}\text { Average of infected } \\
\text { cases } / 6 \text { days }\end{array}$ & Infection rate & Infection rate (\%) \\
\hline February & 29-Feb & 2.6 & & \\
\hline \multirow{5}{*}{ March } & 06-Mar & 5.3 & 2.051 & 205.1 \\
\hline & 12-Mar & 7.2 & 1.344 & 134.4 \\
\hline & 18-Mar & 11.7 & 1.628 & 162.8 \\
\hline & 24-Mar & 25.5 & 2.186 & 218.6 \\
\hline & 30-Mar & 52.3 & 2.052 & 205.2 \\
\hline \multirow[t]{5}{*}{ April } & 05-Apr & 55.3 & 1.057 & 105.7 \\
\hline & 11-Apr & 59.5 & 1.075 & 107.5 \\
\hline & 17-Apr & 27.3 & 0.459 & 45.9 \\
\hline & 23-Apr & 32.5 & 1.189 & 118.9 \\
\hline & 29-Apr & 54.3 & 1.672 & 167.2 \\
\hline \multirow[t]{5}{*}{ May } & 05-May & 74.3 & 1.368 & 136.8 \\
\hline & 11-May & 64.5 & 0.868 & 86.8 \\
\hline & 17-May & 97.7 & 1.514 & 151.4 \\
\hline & 23-May & 144.7 & 1.481 & 148.1 \\
\hline & 29-May & 266.8 & 1.844 & 184.4 \\
\hline \multirow[t]{5}{*}{ June } & 04-Jun & 494.5 & 1.853 & 185.3 \\
\hline & 10-Jun & 1095.7 & 2.216 & 221.6 \\
\hline & 16-Jun & 1214.3 & 1.108 & 110.8 \\
\hline & 22-Jun & 1662.7 & 1.369 & 136.9 \\
\hline & 28-Jun & 2121.0 & 1.276 & 127.6 \\
\hline \multirow[t]{6}{*}{ July } & 04-Jul & 2158.7 & 1.018 & 101.8 \\
\hline & 10-Jul & 2351.0 & 1.089 & 108.9 \\
\hline & 16-Jul & 2281.3 & 0.970 & 97.0 \\
\hline & Mean & 598.4 & 1.4 & 142.13 \\
\hline & \pm & \pm & \pm & \pm \\
\hline & SD & 862.4 & 0.5 & 45.92 \\
\hline
\end{tabular}




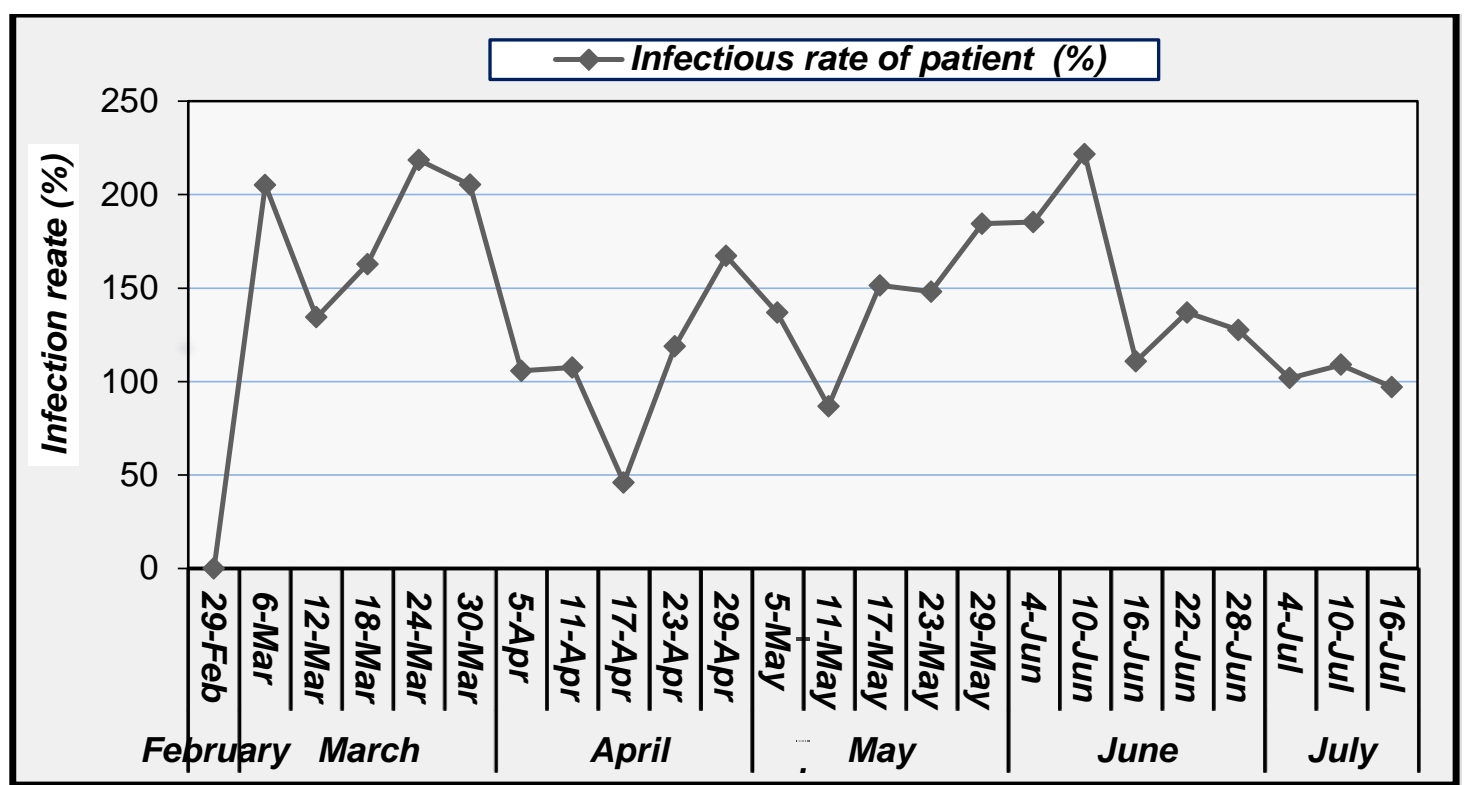

Figure 1-The average of infection rates for every 6 days in Iraq since the beginning of the pandemic until the $16^{\text {th }}$ of July 2020.

On the other hand, the average rate of recovery for every six days in Iraq since the beginning of the pandemic until the $16^{\text {th }}$ July 2020 was $52.61 \pm 42.63 \%$.It is clear from Figure- 2 that the rate of recovered cases $(>100 \%)$ in the period between 17-23 April was higher than that of the newly recorded cases, whereas the rate of death was $<2 \%$,

Figure-3 reveals that the highest death rate was in the last two weeks of March, reaching higher than $10 \%$. However, this might not be very precise since many cases were possibly not registered, while others were asymptomatic. In July, the average death rate for every six days reached about $4 \%$, whereas the overall average death rate for every six days in Iraq was $3.7 \pm 2.31 \%$.

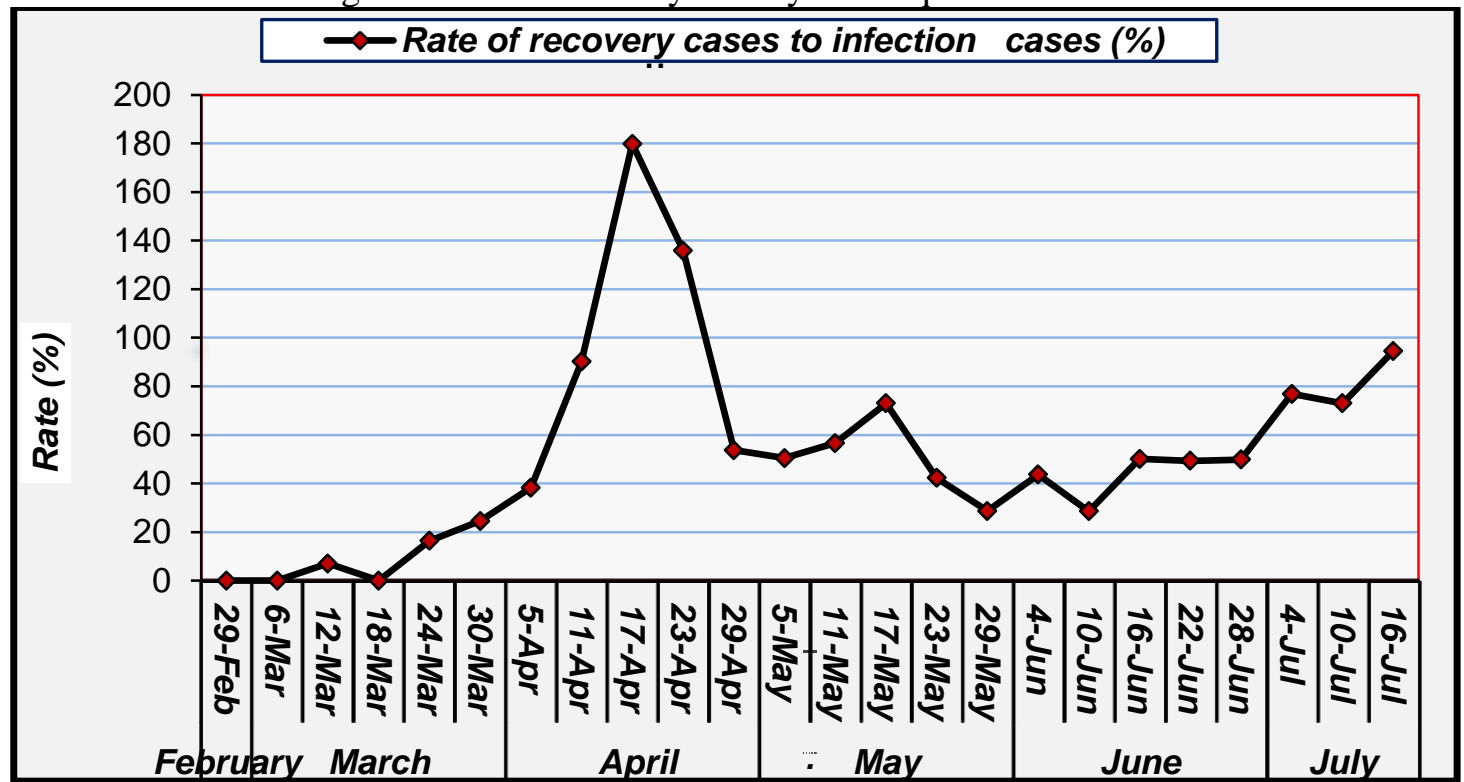

Figure 2- The rate of average recovery to average infection cases for every 6 days since the beginning of the pandemic to the $16^{\text {th }}$ of July 2020. 


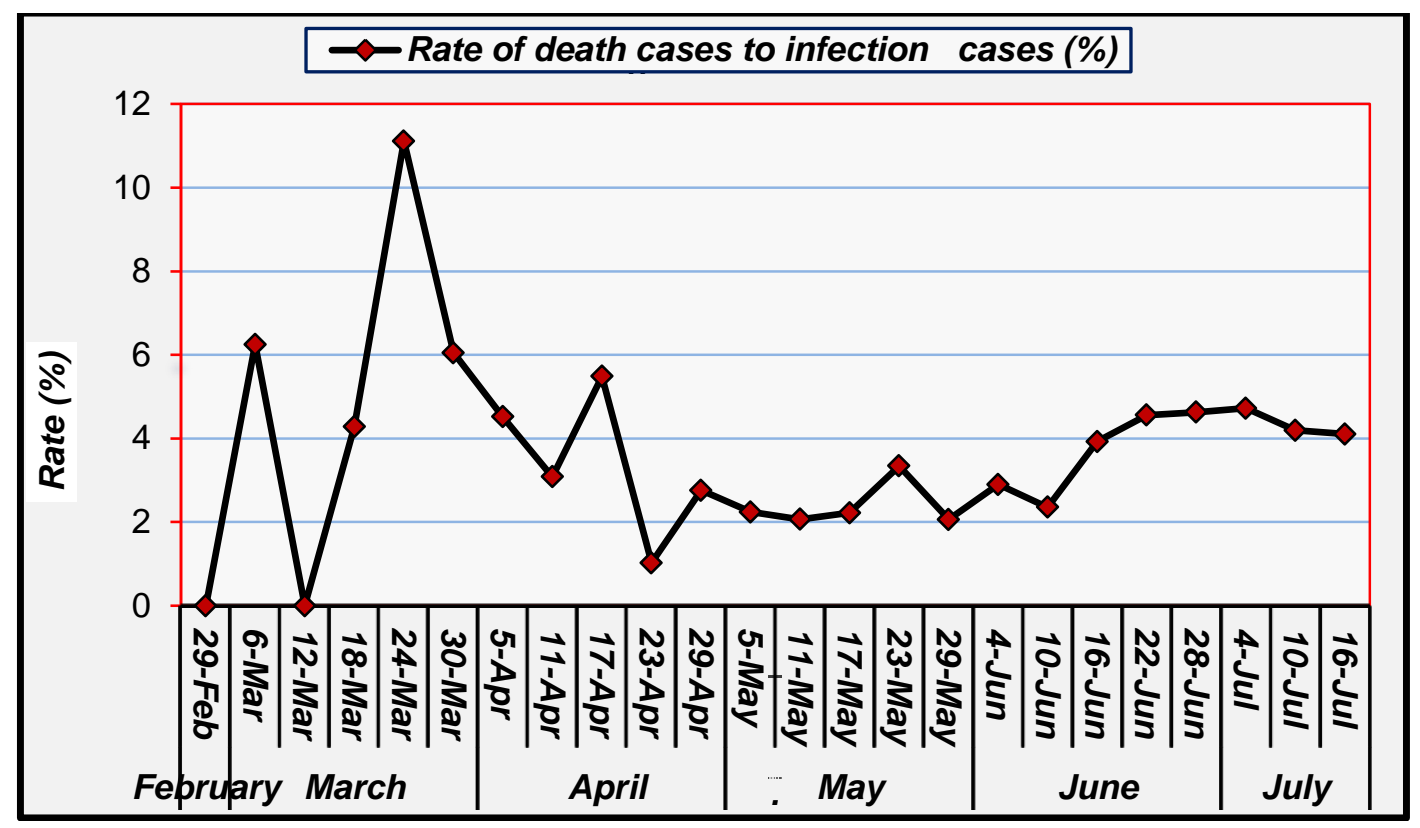

Figure 3- The rate of average death to average infection cases for every 6 days since the beginning of the pandemic to the $16^{\text {th }}$ of July.

These data reflect the importance of increasing the number of tests to achieve more precise information about the pandemic. Therefore, the number of the performed tests was included in this study; however, no data about the number of the performed tests in February and March are available. The number of the performed tests for every 6 days increased from 1275 to about 13958 tests during April, with a total average of $6988 \pm 4171$, but this increase is still not sufficient to cover the high number of infection cases.

Table 2-Average number of tests for every 6 days since the beginning of the pandemic to the $16^{\text {th }}$ of July.

\begin{tabular}{|c|c|c|}
\hline Months & Date & Average of tests/6 days \\
\hline \multirow[t]{4}{*}{ April } & 11- Apr. & 1275.2 \\
\hline & 17-Apr & 1993.0 \\
\hline & 23-Apr & 2196.5 \\
\hline & 29-Apr & 3637.7 \\
\hline \multirow[t]{5}{*}{ May } & 05-May & 4462.7 \\
\hline & 11-May & 2702.8 \\
\hline & 17-May & 3333.3 \\
\hline & 23-May & 5413.5 \\
\hline & 29-May & 5758.2 \\
\hline \multirow[t]{5}{*}{ June } & 04-Jun & 9254.7 \\
\hline & 10-Jun & 9711.2 \\
\hline & 16-Jun & 9968.2 \\
\hline & 22-Jun & 10830.2 \\
\hline & 28-Jun & 10938.7 \\
\hline \multirow[t]{7}{*}{ July } & 04-Jul & 11404.8 \\
\hline & 10-Jul & 11952.2 \\
\hline & 16-Jul & 13957.7 \\
\hline & & \\
\hline & Mean & 6987.7 \\
\hline & \pm & \pm \\
\hline & SD & 4171.3 \\
\hline
\end{tabular}




\section{Baghdad Governorate}

The collected data for each governorate were subjected to the same type of analysis. Table- 3 shows the average number of infection cases and rates for every 6 days in Baghdad governorate since the beginning of the pandemic to the $16^{\text {th }}$ of July. It is clear that the range of infection cases for every 6 days during March- April was 2-20 cases. However, the infection rate was $>1$, indicating the low number of the performed tests. Then, the average number of new cases for every 6 days increased gradually during the period May- 16 July, indicating an active spread of the pandemic in Baghdad without any decrease in the number. The total average of the new cases for every 6 days was $206 \pm$ 264. The SD value is higher than that of the mean, indicating the high number of non-registered cases in Baghdad. The average of infection rate for every 6 days in Baghdad since the beginning of the pandemic to the $16^{\text {th }}$ of July was $1.4 \pm 0.4$.

All these data indicate that the pandemic was active from the first moment in Baghdad. However, the activity appeared to be low due to the low number of performed tests and low number of cases at the beginning. The spread was very clear in a serial manner, as shown in Figure-4, and the infection rate was out of control.

Table 3-The average of infection cases and rates for every 6 days in Baghdad governorate since the beginning of the pandemic to the $16^{\text {th }}$ of July

\begin{tabular}{|c|c|c|c|c|}
\hline Month & Date & $\begin{array}{c}\text { Average of } \\
\text { infection cases/6 } \\
\text { days }\end{array}$ & $\underline{\text { Infection rate }}$ & Infection rate (\%) \\
\hline February & 29-Feb & 1.000 & & \\
\hline \multirow[t]{5}{*}{ March } & 06-Mar & 2.167 & 2.167 & 216.667 \\
\hline & 12-Mar & 4.000 & 1.846 & 184.615 \\
\hline & 18-Mar & 8.000 & 2.000 & 200.000 \\
\hline & 24-Mar & 5.667 & 0.708 & 70.833 \\
\hline & 30-Mar & 10.667 & 1.882 & 188.235 \\
\hline \multirow[t]{5}{*}{ April } & 05-Apr & 8.167 & 0.766 & 76.563 \\
\hline & 11-Apr & 12.500 & 1.531 & 153.061 \\
\hline & 17-Apr & 8.500 & 0.680 & 68.000 \\
\hline & 23-Apr & 11.500 & 1.353 & 135.294 \\
\hline & 29-Apr & 20.333 & 1.768 & 176.812 \\
\hline \multirow[t]{5}{*}{ May } & 05-May & 34.500 & 1.697 & 169.672 \\
\hline & 11-May & 44.667 & 1.295 & 129.469 \\
\hline & 17-May & 69.500 & 1.556 & 155.597 \\
\hline & 23-May & 111.167 & 1.600 & 159.952 \\
\hline & 29-May & 195.000 & 1.754 & 175.412 \\
\hline \multirow[t]{5}{*}{ June } & 04-Jun & 264.167 & 1.355 & 135.470 \\
\hline & 10-Jun & 512.167 & 1.939 & 193.880 \\
\hline & 16-Jun & 496.333 & 0.969 & 96.909 \\
\hline & 22-Jun & 517.667 & 1.043 & 104.298 \\
\hline & 28-Jun & 609.000 & 1.176 & 117.643 \\
\hline \multirow[t]{6}{*}{ July } & 04-Jul & 643.167 & 1.056 & 105.610 \\
\hline & 10-Jul & 664.667 & 1.033 & 103.343 \\
\hline & 16-Jul & 698.500 & 1.051 & 105.090 \\
\hline & Mean & 206.375 & 1.401 & 140.105 \\
\hline & \pm & \pm & \pm & \pm \\
\hline & SD & 263.583 & 0.440 & 43.964 \\
\hline
\end{tabular}




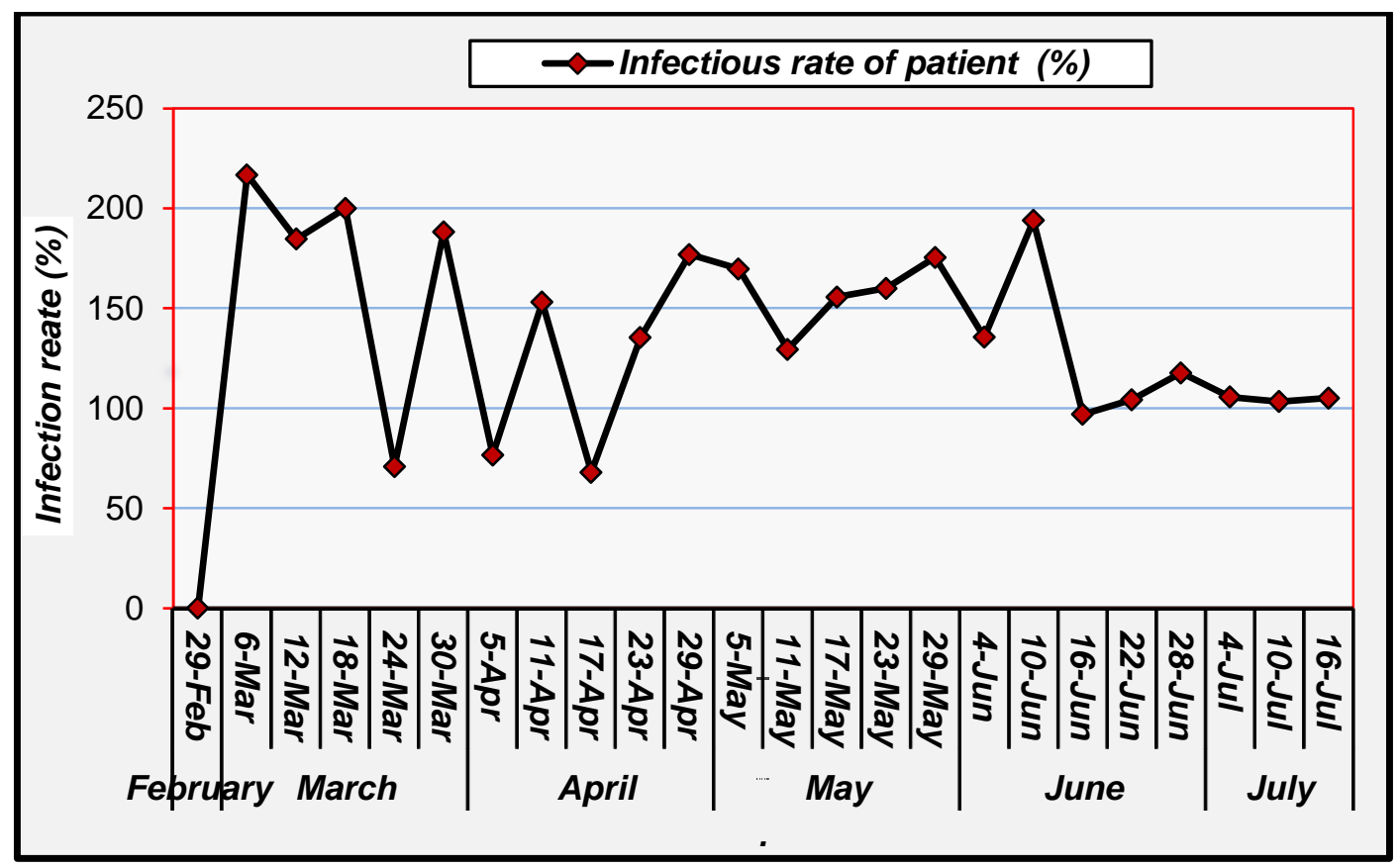

Figure 4-The average infection rates for every 6 days in Baghdad since the beginning of the pandemic to the $16^{\text {th }}$ of July.

The results of the recovery rate for every 6 days in Baghdad since the beginning of the pandemic to the $16^{\text {th }}$ of July are shown in Figure-5. The highest value was recorded in the $17^{\text {th }}$ of April, being higher than that of the newly recorded cases. Also, the value was $100 \%$ in the $4^{\text {th }}$ of July, indicating the success of some treatment protocols. However, there were no clear data about types of treatment protocols that were used in Iraq. The total average of recovery for every 6 days in Baghdad was $48 \pm$ $36 \%$.

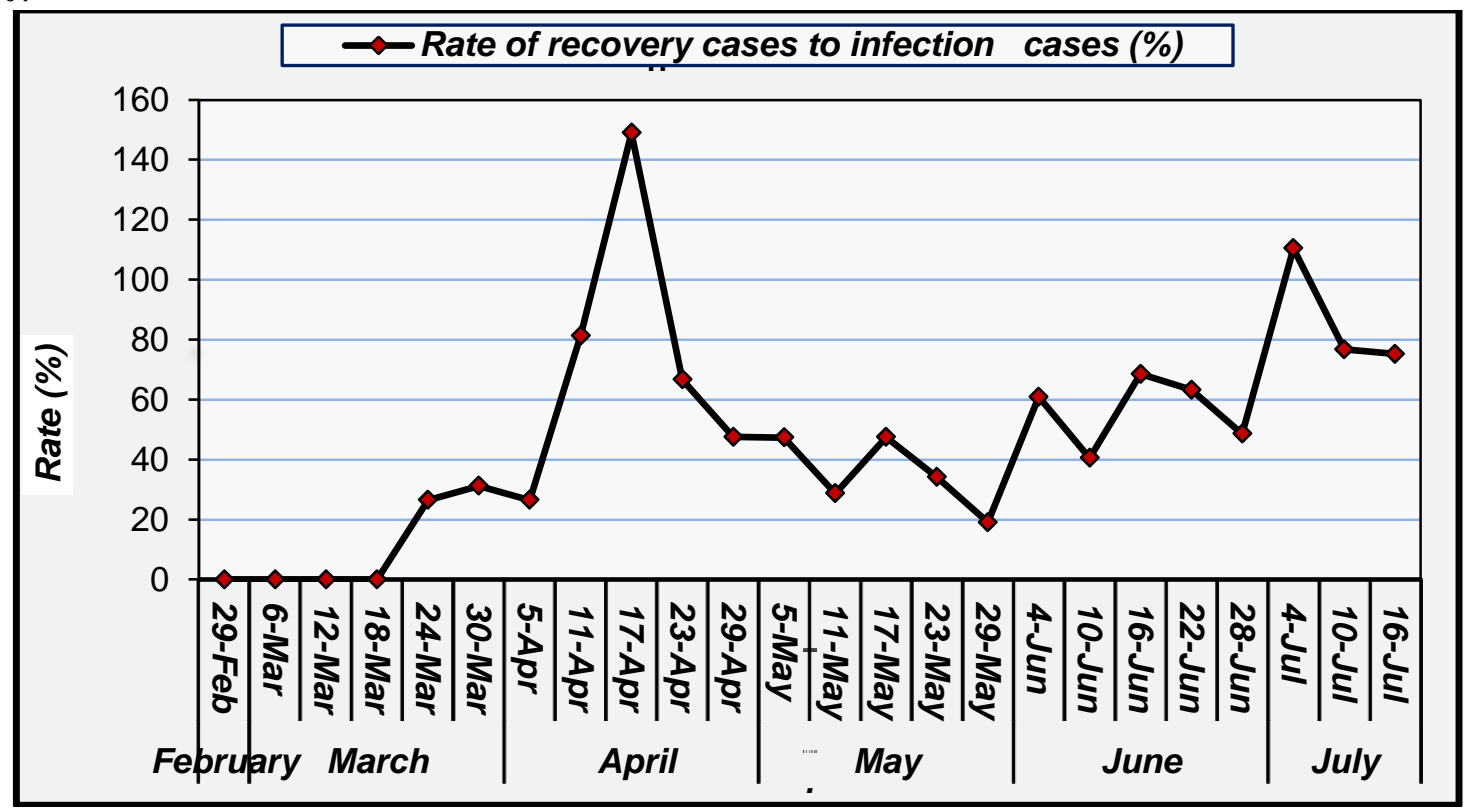

Figure 5-The average recovery rates for every 6 days in Baghdad since the beginning of the pandemic to the $16^{\text {th }}$ of July.

On the other hand, the death rate was higher than that expected, which might be due the high number of infection cases that were not officially registered (Figure-6). The value was higher than $20 \%$ in the $24^{\text {th }}$ of March, then it decreased to lower than 5\% during 23 April- 16 June. The average 
death rate was 5.5 5.2. It should be noted that there were no official data that could explain the main causes of deaths and if there were sex or age variations.

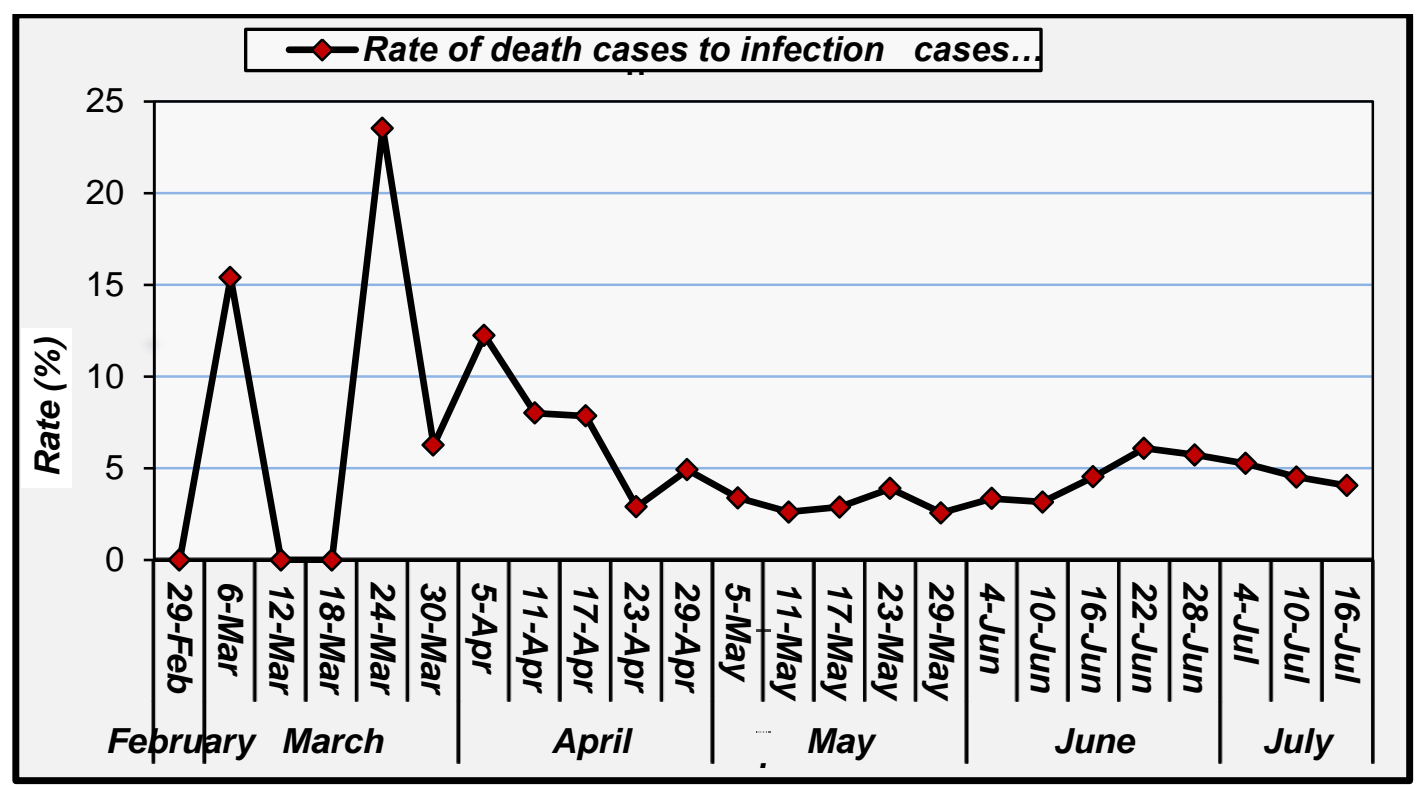

Figure 6-The average death rates for every 6 days in Baghdad since the beginning of the pandemic to the $16^{\text {th }}$ of July.

\section{Comparison between Iraqi governorates}

Similar statistical analysis was performed for each governorate following the pandemic for the period of 24 Feb-16 July. As shown in Table-4, there was a emarkable variation in the spread of the pandemic from one governorate to another. Baghdad showed the highest total number of infection cases for every 6 days (29718, mean 206.4 \pm 263.6$)$. The high SD value indicates that the presence of higher numbers of unregistered infections in Baghdad. Following Baghdad, Sulaymaniyah, Basra, and Dhi Qar showed highest total numbers of infections until the $16^{\text {th }}$ of July, respectively, while Dohuk and Ninewa showed the lowest total numbers (305, 489, respectively). Other governorates were varying in their total numbers (Figure-7).

Similarly, the total average infection rates for every 6 days varied from one governorate to another, all having values of $>1$, indicating that the pandemic was active in all Iraq. Babil showed the

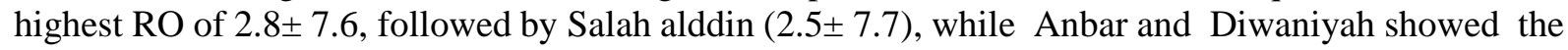
lowest values of $0.8 \pm 1.6$ and $0.8 \pm 1.1$ respectively. Since the SD value is higher than that of the mean in these two governorates, this indicates that the data is not precise. This may be due to the low number of tests or the high number of unregistered cases in these two, as well as in other, governorates (Figure-8)

Table 4-Total number of infection cases, average of infection cases, average of infection rates, and average of recovery and death rates for every 6 days in all Iraq's governorates since the binging of the pandemic to the $16^{\text {th }}$ of July 2020 .

\begin{tabular}{|c|c|c|c|c|c|c|c|c|c|c|c|c|c|}
\hline \multirow[t]{2}{*}{ Governorates } & \multirow{2}{*}{$\begin{array}{c}\text { Total } \\
\text { number } \\
\text { of } \\
\text { infection } \\
\text { cases }\end{array}$} & \multicolumn{3}{|c|}{$\begin{array}{l}\text { Average of infection } \\
\text { cases/6 days }\end{array}$} & \multicolumn{3}{|c|}{ Infection rate } & \multicolumn{3}{|c|}{$\begin{array}{l}\text { Rate of recovery to } \\
\text { infection cases }(\%)\end{array}$} & \multicolumn{3}{|c|}{$\begin{array}{l}\text { Rate of death to } \\
\text { infection cases } \\
(\%)\end{array}$} \\
\hline & & Mean & \pm & SD & Mean & \pm & SD & Mean & \pm & SD & Mean & \pm & SD \\
\hline Babil & 3556 & 24.7 & \pm & 43.4 & 2.8 & \pm & 7.6 & 57.3 & \pm & 64.9 & 18.4 & \pm & 63.3 \\
\hline Salah alddin & 1984 & 13.8 & \pm & 31.5 & 2.5 & \pm & 7.7 & 28.9 & \pm & 42.3 & 1.0 & \pm & 2.0 \\
\hline Mesan & 4074 & 28.3 & \pm & 45.7 & 2.3 & \pm & 4.6 & 88.2 & \pm & 188.9 & 2.2 & \pm & 3.9 \\
\hline Muthna & 1258 & 8.8 & \pm & 15.3 & 2.2 & \pm & 3.1 & 155.1 & \pm & 284.4 & 3.6 & \pm & 7.3 \\
\hline Kirkuk & 2850 & 19.8 & \pm & 34.3 & 2.1 & \pm & 3.6 & 158.6 & \pm & 433.5 & 4.7 & \pm & 11.0 \\
\hline
\end{tabular}




\begin{tabular}{|c|c|c|c|c|c|c|c|c|c|c|c|c|c|}
\hline Wasit & 4892 & 34.0 & \pm & 55.2 & 2.1 & \pm & 3.5 & 126.4 & \pm & 347.6 & 2.2 & \pm & 5.2 \\
\hline Basra & 6422 & 44.6 & \pm & 63.1 & 2.1 & \pm & 3.6 & 65.0 & \pm & 85.9 & 7.1 & \pm & 20.1 \\
\hline Karbala & 3708 & 25.8 & \pm & 41.0 & 1.9 & \pm & 2.2 & 78.7 & \pm & 103.2 & 7.9 & \pm & 21.3 \\
\hline Dhi Qar & 5874 & 40.8 & \pm & 68.4 & 1.8 & \pm & 2.1 & 90.4 & \pm & 137.0 & 10.0 & \pm & 25.8 \\
\hline Erbil & 2547 & 17.7 & \pm & 26.5 & 1.7 & \pm & 2.6 & 372.3 & \pm & 1340.8 & 1.4 & \pm & 2.8 \\
\hline Dohuk & 305 & 2.1 & \pm & 3.5 & 1.6 & \pm & 2.8 & 54.0 & \pm & 75.2 & 0.0 & \pm & 0.0 \\
\hline Najaf & 4436 & 30.8 & \pm & 46.0 & 1.6 & \pm & 1.3 & 91.7 & \pm & 136.1 & 1.5 & \pm & 3.1 \\
\hline Baghdad & $\mathbf{2 9 7 1 8}$ & $\mathbf{2 0 6 . 4}$ & \pm & $\mathbf{2 6 3 . 6}$ & 1.4 & \pm & 0.4 & 47.9 & \pm & 36.0 & 5.5 & \pm & 5.2 \\
\hline Sulaymaniyah & 7232 & 50.2 & \pm & 77.6 & 1.4 & \pm & 1.4 & 130.1 & \pm & 296.2 & 2.3 & \pm & 2.8 \\
\hline Diyala & 3597 & 25.0 & \pm & 46.6 & 1.4 & \pm & 1.8 & 50.0 & \pm & 102.1 & 13.5 & \pm & 28.6 \\
\hline Ninewa & 489 & 3.4 & \pm & 5.5 & 1.3 & \pm & 3.3 & 33.2 & \pm & 51.5 & 1.2 & \pm & 4.1 \\
\hline Diwaniyah & 3568 & 24.8 & \pm & 44.0 & 0.8 & \pm & 1.1 & 57.9 & \pm & 126.3 & 2.4 & \pm & 6.8 \\
\hline Anbar & 701 & 4.9 & \pm & 9.0 & 0.8 & \pm & 1.6 & 41.5 & \pm & 114.9 & 2.2 & \pm & 3.8 \\
\hline Total for Iraq & 87211 & 598.3 & \pm & 862.5 & 1.4 & \pm & 0.5 & 52.6 & \pm & 42.6 & 3.7 & \pm & 2.3 \\
\hline
\end{tabular}

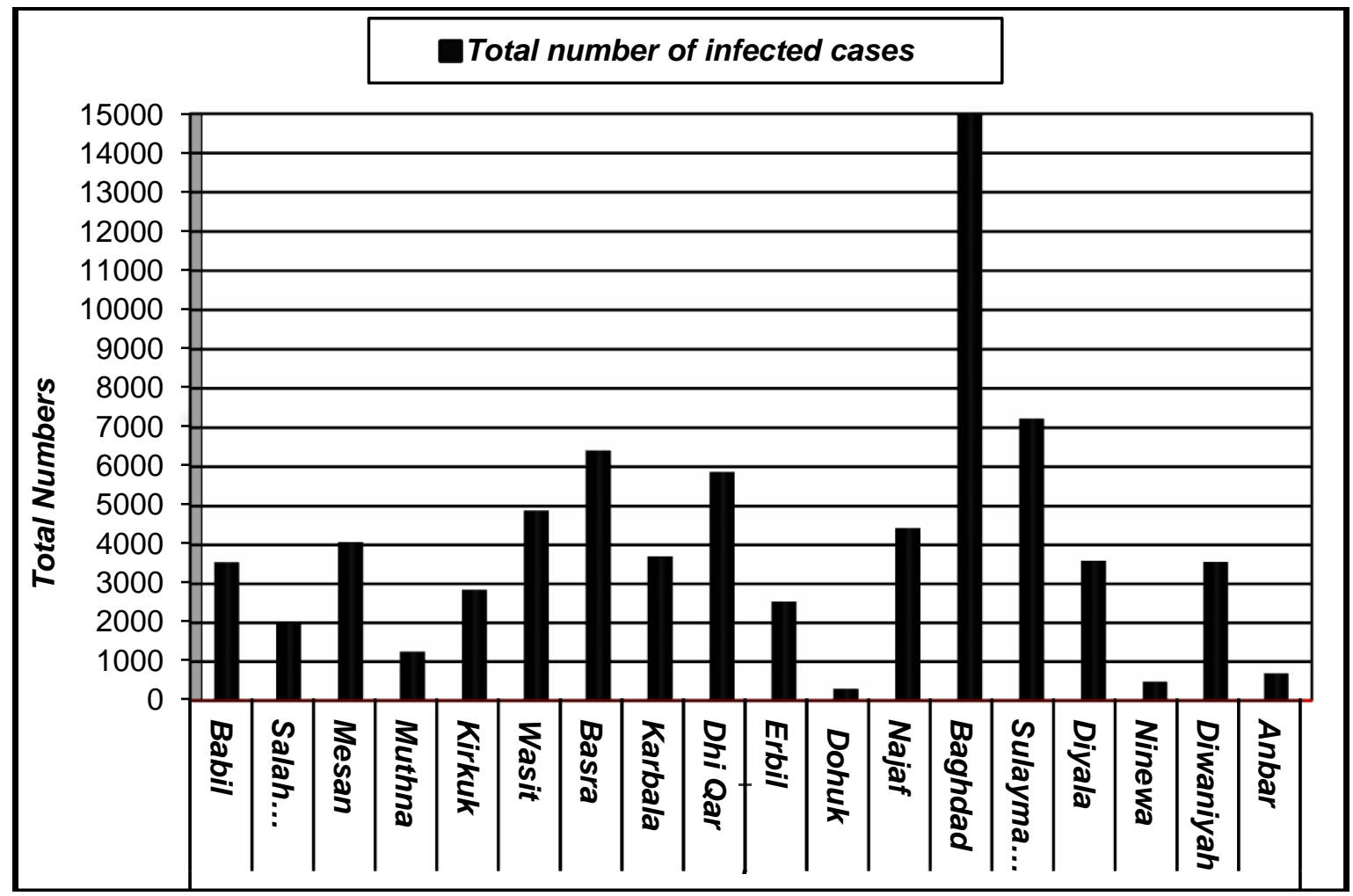

Figure 7-Total number of infection cases in all Iraqi governorates since the binging of the pandemic to the $16^{\text {th }}$ of July. 


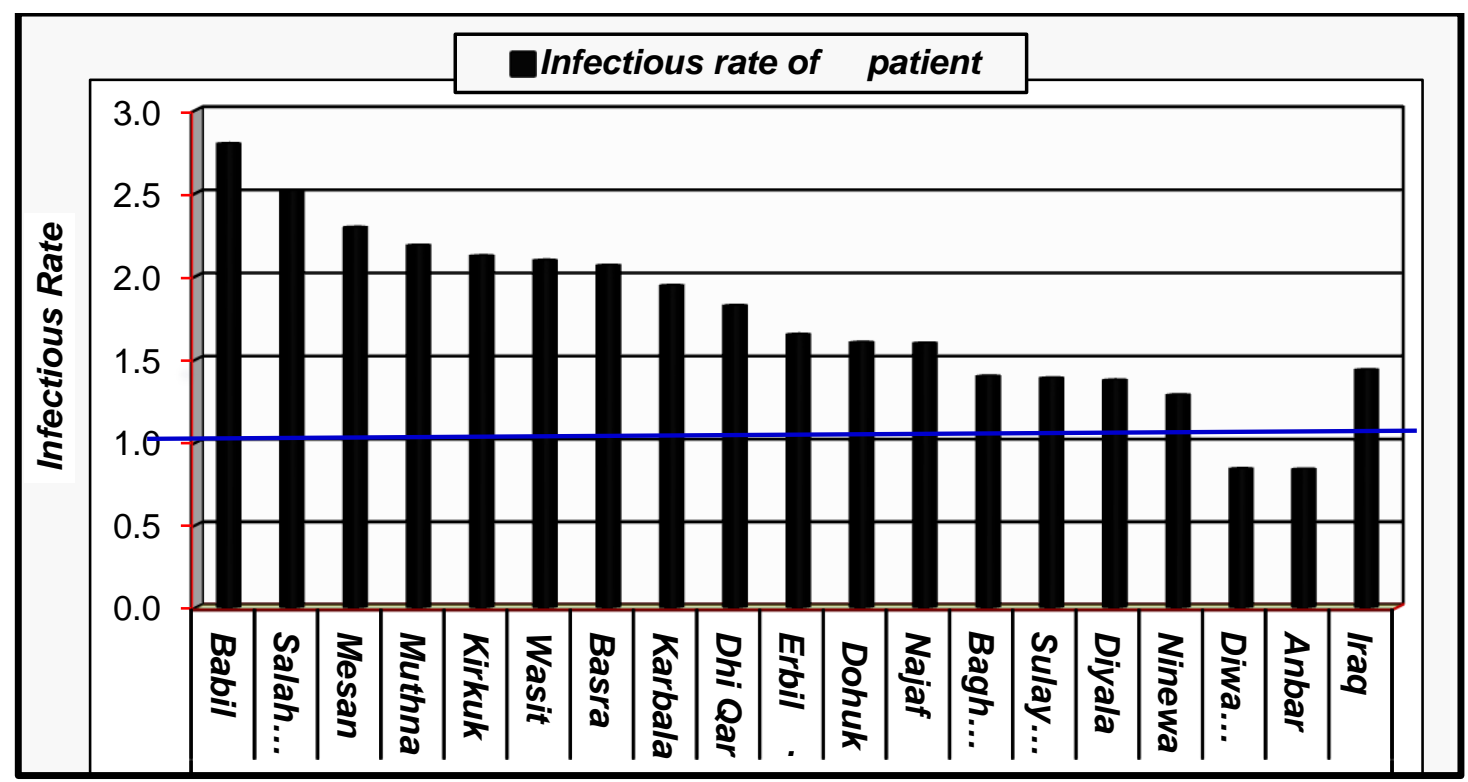

Figure 8- The average of infection rates for every 6 days in all Iraqi governorates since the beginning of the pandemic to the $16^{\text {th }}$ of July.

Similarly, there were clear variations in the average of recovery rates for every 6 days among all governorates. Erbil, Kirkuk and Muthna showed the highest average recovery rate, whereas Salah alddin and Anbar showed the lowest (Figure-9). This may indicate variations in the approached that were followed, in terms of diagnosis, tests, and modes of management.

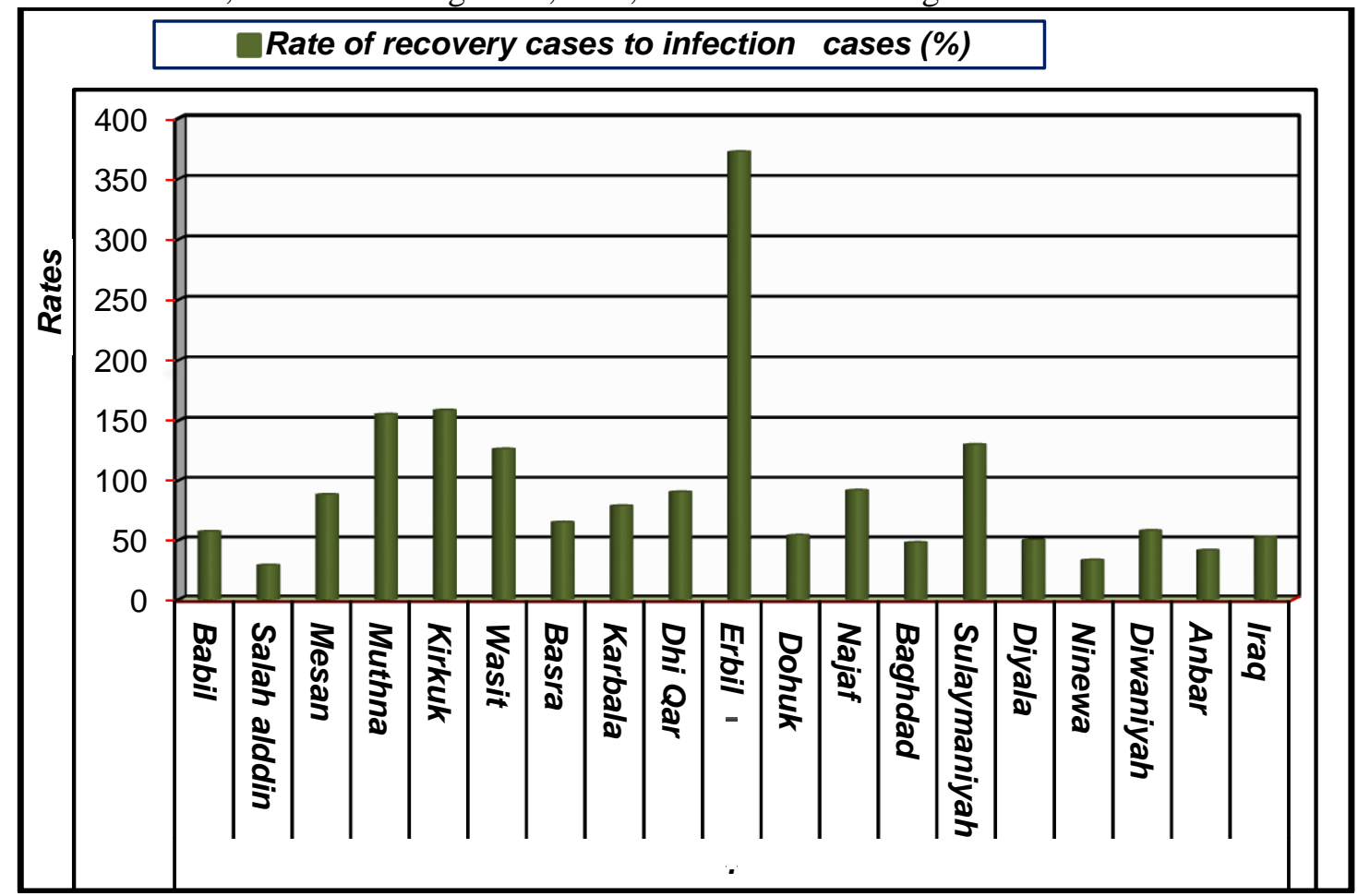

Figure 9- The average recovery rates for every 6 days in all Iraqi governorates since the beginning of the pandemic to the $16^{\text {th }}$ of July.

There were large variations among all governorates in the average of death for every 6 days. Babil was the highest with a value of $18.4 \pm 63.3 \%$. Again, this high SD reflects unregistered cases. Diyala showed similarly high death rates $(13.5 \pm 28.6)$, while Dohuk did not show any death case until the $16^{\text {th }}$ of July, which indicates that the pandemic in Dohuk was under control during that period. This is supported by the low number of total infection cases in this governorate (305).

It was reported that the complications of COVID-19 include impaired functions of the heart, brain, lung, liver, kidney, and the coagulation system. The disease can cause myocarditis, cardiomyopathy, 
ventricular arrhythmias, and hemodynamic instability $[16,17]$. Venous and arterial thromboembolism may occur in 10-25\% of hospitalized patients [18]. In the intensive care unit, venous and arterial thromboembolic complications may occur in $31 \%$ to $59 \%$ of patients with COVID-19 [19]. Bleeding was reported in 10\%-25\% and septic shock in 6\% [20]. Children are less susceptible to the infection with SARSCoV2. The explanations could include their strong innate immune response as well as the upregulation of virus receptors in their lungs. As a result, less than $7 \%$ of children needed to admit to hospital [21, 22]. However, no confirmed data are available about children's infection in Iraq, which is very important in evaluating the spread of the pandemic. Furtheremore, no Iraqi official data are available about any of the complications or the age, sex, and medical hisory of the death cases, which makes it difficult for this analysis to explain the reasons for high death rates and their variations between the Iraqi proviences. These variations migh be possibly due to many unregestered cases, which varies between one provience to another. The may also be related to the low number of performed tests, as it is known that the death rates depend on the total number of infection cases, which is difficult to evaluate sepecially if non symptomatic cases are included. In addtion, it is not clear if there is an exchange in the medical experience between the proviences or not. It is also not clear if males are more sucuptible to infection as comapred to female, as it was reported in other countries. All these are considred as missing factors and shortages of the present study. However, the analyses performed through the present work are highly needed by other researchers. More detaileddata related to this work were published in arabic launguage elsewhere [23].

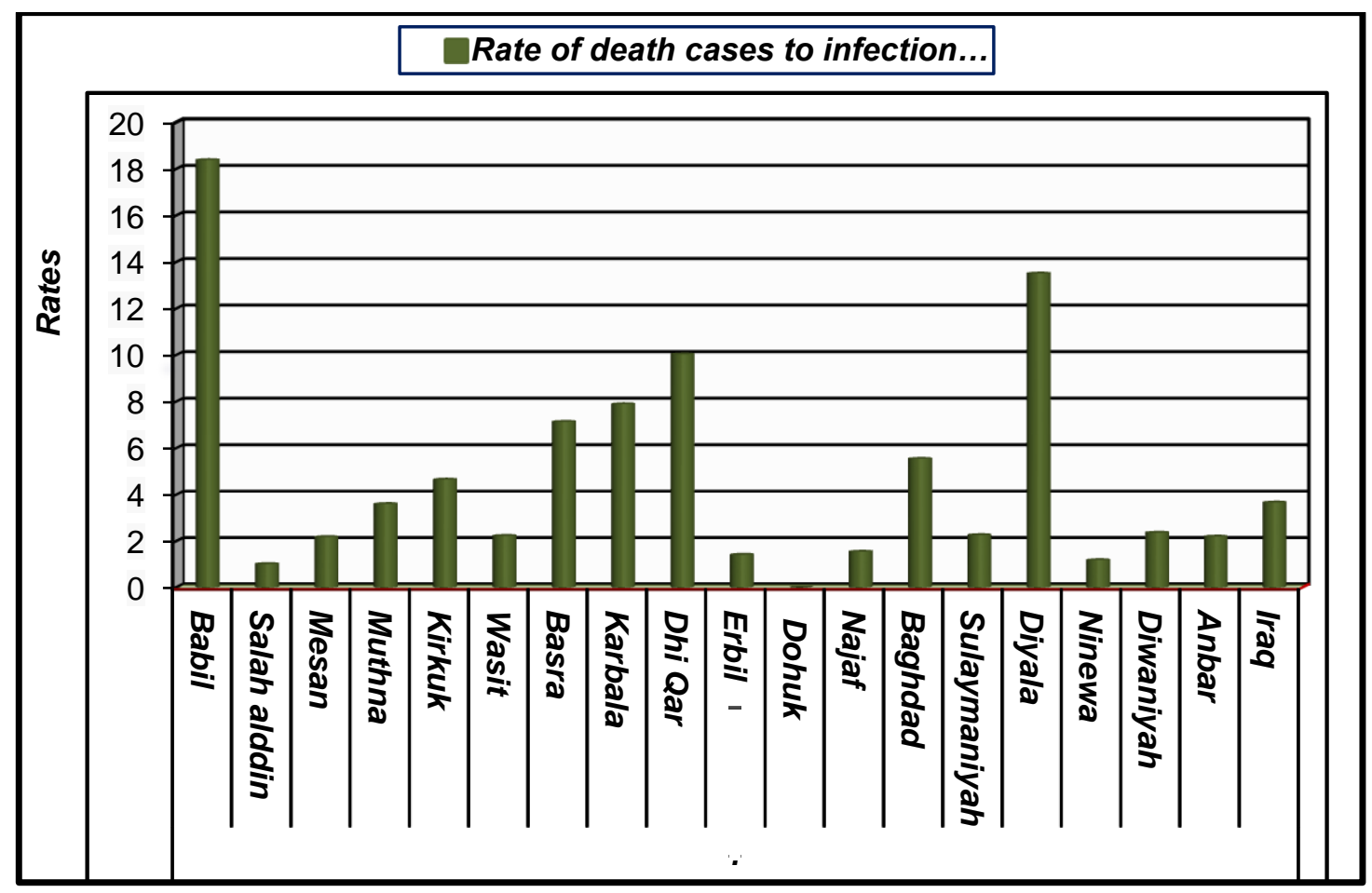

Figure 10- The average death rates for every 6 days in all Iraqi governorates since the beginning of the pandemic to the $16^{\text {th }}$ of July 2020 .

As a conclusion from the presented statistical analysis, it is clear that the pandemic was active in Iraq since $24 \mathrm{Feb} 202$, it was spreading slowly until the time of writing this article, and there were big variations between Iraq's provinces, whether in the total number of infected individuals or in RO value and recovery and death rates.

It is recommended to increase the number of tested samples at least to the double. In addition, there is a need to lock down some local locations or areas where the pandemic is highly active. It is recommended to explain the danger of Covid19 scientifically to citizens and children by special education programs. Statistical analysis-based studies are highly recommended as they explain the activity of virus spreading in different places and point out the gaps to be avoided. Finally, the exchange of scientific and medical information is needed among different governorates in Iraq. 


\section{References}

1. Rodriguez-Morales AJ, Bonilla-Aldana DK, Balbin-Ramon GJ, Rabaan AA, Sah R, PanizMondolfi A, Pagliano P, Esposito S. 2020. History is repeating itself: Probable zoonotic spillover as the cause of the 2019 novel Coronavirus Epidemic. Infez Med, 28(1): 3-5.1.

2. Zhu N, Zhang D, Wang W, Li X, Yang B, Song J, Zhao X, Huang B, Shi W, Lu R, Niu P, Zhan F, Ma X, Wang D, Xu W, Wu G, Gao GF, Tan W, China Novel Coronavirus Investigating and Research Team. 2020. A Novel Coronavirus from Patients with Pneumonia in China, 2019. N Engl J Med 10.1056/NEJMoa2001017.

3. Munster VJ, Koopmans M, van Doremalen N, van Riel D, de Wit E. 2020. A novel Coronavirus emerging in China-key questions for impact assessment $N$ Engl J Med 10.1056/NEJMp2000929.

4. Fan Y, Zhao K, Shi ZL, Zhou P. 2019. Bat Coronaviruses in China. Viruses, 11(3): 210.

5. CDC. 2019. Diagnostic Tests for COVID-19.

6. Su S, Wong G, Shi W, Liu J, Lai ACK, Zhou J, Liu W, Bi Y, Gao GF. 2016. Epidemiology, genetic recombination, and pathogenesis of Coronaviruses. Trends Microbiol, 24(6): 490-502.

7. $\mathrm{Ng}$ OW, Tan YJ. 2017. Understanding bat SARS-like coronaviruses for the preparation of future corona virus outbreaks-Implications for coronavirus vaccine development. Hum Vaccin Immunother, 13(1): 186-189.

8. Chen J. 2020. Pathogenicity and transmissibility of 2019-nCoV-A quick overview and comparison with other emerging viruses. Microbes Infect S1286-4579(20)30026-5.

9. Wu A, Peng Y, Huang B, Ding X, Wang X, Niu P, Meng J, Zhu Z, Zhang Z, Wang J, Sheng J, Quan L, Xia Z, Tan W, Cheng G, Jiang T. 2020. Genome composition and divergence of the novel Coronavirus (2019-nCoV) originating in China. Cell Host Microbe S1931-3128(20)30072$\mathrm{X}$.

10. Marco D'Arienzo and Angela Conig. 2020. Assessment of the SARS-CoV-2 basic reproduction number,RO, basedonthe early phase of COVID-19 outbreak in Italy. Biosafety and Health, 2: 5759.

11. Ebrahim Sahafizadeh and Samaneh Sartoli. 2020. Estimating the reproduction number of COVID-19 in Iran using epidemic modeling. medRxiv preprint doi: https://doi.org /10.1101 12020.03.20.20038.

12. Motasem N. Saidana, Mohammad A. Shboolb, Omar Suleiman Arabeyyatc, Sameh T. AlShihabib, Yousef Al Abdallatb , Mahmoud A. Barghashb , Hakam Saidan.2020. Estimation of the probable outbreak size of novel coronavirus (COVID-19) in social gathering events and industrial activities. International Journal of Infectious Diseases, 98(2020): 321-327

13. Coronavirus Disease. 2019. (COVID-19).

14. Roy M. Anderson \& Robert M. May.1985. Vaccination and herd immunity to infectious diseases. Nature, 318: 323-329.

15. Delamater, P.L., Street, E.J., Leslie, T.F., Yang, Y.T., and Jacobsen, K.H. 2019. Complexity of the basic reproduction number (RO). Emerg. Infect. Dis. 25: 1-4.

16. Lloyd-Smith, J.O., Schreiber, S.J., Kopp, P.E., and Getz, W.M. 2005. Super-spreading and the effect of individual variation on disease emergence. Nature, 438: 355-359.

17. Sanche, S., Lin, Y.T., Xu, C., Romero-Severson, E., Hengartner, N., and Ke, R. 2020. High contagiousness and rapid spread of severe acute respiratory syndrome coronavirus 2. Emerg. Infect. Dis. 26.

18. Docherty AB, Harrison EM, Green CA, et al; ISARIC4C investigators. Features of 20133 UK patients in hospital with COVID-19 using the ISARIC WHO Clinical Characterisation Protocol: prospective observational cohort study. BMJ. 2020; 369:m1985.

19. Grasselli G, Zangrillo A, Zanella A, et al. 2020. COVID-19 Lombardy ICU Network. Baseline characteristics and outcomes of 1591 patients infected with SARS-CoV-2 admitted to ICUs of the Lombardy Region, Italy. JAMA. 323(16): 1574-1581.

20. Huang C, Wang Y, Li X, et al. 2020. Clinical features of patients infected with 2019 novel coronavirus in Wuhan, China. Lancet.; 395(10223): 497-506.

21. Lechien JR, Chiesa-Estomba CM, De Siati DR, et al. 2020. Olfactory and gustatory dysfunctions as a clinical presentation of mild-to-moderate forms of the coronavirus disease (COVID-19): a multicenter European study. Eur Arch Otorhinolaryngol. 277(8): 2251-2261. 
22. Levin M. 2020. Childhood multisystem inflammatory syndrome: a new challenge in the pandemic. N Engl J Med. Published online June 29, 2020.

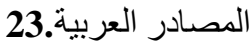

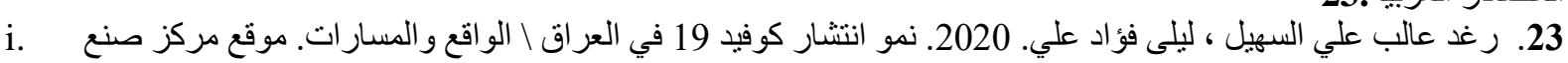

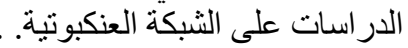

